\title{
Evaluation of the In vitro Activity of Ceftazidime- Avibactam and Ceftolozane-Tazobactam against Ceftazidime-Resistant Pseudomonas aeruginosa Isolates
}

\section{Seftazidim-Avibactam ve Seftolozan-Tazobaktam'ın Seftazidim Dirençli Pseudomonas aeruginosa İzolatlarına Karșı İn vitro Aktivitesinin Deg̃erlendirilmesi}

\author{
Melek BiLGIN (IID), Eșe BAȘBULUT (IiD), Hacer ișLER (IID)
}

Clinic of Medical Microbiology, Health Sciences University Samsun Training and Research Hospital, Samsun, Turkey

Cite this article as: Bilgin $M$, Başbulut $E$, ișler $\mathrm{H}$. Evaluation of the in vitro activity of ceftazidime-avibactam and ceftolozane-tazobactam against ceftazidime-resistant Pseudomonas aeruginosa isolates. FLORA 2021;26(4):713-9.

\begin{abstract}
Introduction: This study aimed to assess the in vitro efficacy of ceftazidime/avibactam (CZA) and ceftolozane/tazobactam (C/T) against ceftazidime resistant Pseudomonas aeruginosa clinical isolates from Samsun Training and Research Hospital.

Materials and Methods: A total of 52 unique patient isolates of ceftazidime resistant P. aeruginosa were included in this study. Identification and antimicrobial susceptibilities of the strains were performed using a VITEK $2 \circledast$ automated system. The efficacy of CZA and $\mathrm{C} / T$ were determined by the gradient diffusion method (Liofilchem MIC strip test, Italy). We used the European Committee on Antimicrobial Susceptibility Testing (EUCAST) guidelines for Minimal Inhibitory Concentration interpretation.

Results: Among these 52 strains, 49 (94.2\%) were susceptible to CZA and 51 (98.1\%) to C/T. Both CZA and C/T had better activity than any one of the 3 anti-pseudomonal beta-lactams. Although the susceptibility rates of isolates to CZA and C/T were similar, according to $M I C_{50}$ values $C / T$ (MIC $501 \mu \mathrm{g} / \mathrm{mL}$ ) was 2-fold more potent than CZA (MIC $50^{\prime} 2 \mu \mathrm{g} / \mathrm{mL}$ ).

Conclusion: CZA and C/T showed good activity against ceftazidime-resistant and/or carbapenem-resistant P. aeruginosa isolates and may serve as therapeutic options for infections caused by these organisms. However, further in vitro and in vivo studies are needed to assess the effectiveness of these new antimicrobials against multiple drug resistant P. aeruginosa isolates.
\end{abstract}

Key Words: Ceftazidime-resistant Pseudomonas aeruginosa; Carbapenem-resistant Pseudomonas aeruginosa; Ceftazidime-avibactam; Ceftolozane-tazobactam 
ÖZ

\title{
Seftazidim-Avibactam ve Seftolozan-Tazobaktam'ın Seftazidim Dirençli Pseudomonas aeruginosa İzolatlarına Karșı İn vitro Aktivitesinin Deg̃erlendirilmesi
}

\author{
Melek BILGIN, Eșe BAȘBULUT, Hacer ișLER
}

Sag̃lık Bilimleri Üniversitesi Samsun Eg̃itim ve Araștırma Hastanesi, Tıbbi Mikrobiyoloji Klinig̃i, Samsun, Türkiye

Giriş: Bu çalışmada, Samsun Eğitim ve Araştırma Hastanesi'nde seftazidim dirençli Pseudomonas aeruginosa klinik izolatlarına karşı seftazidim/avibaktam (CZA) ve seftolozan/tazobaktam (C/T)'ın in vitro duyarlılıklarının değerlendirilmesi amaçlanmıştır.

Materyal ve Metod: Seftazidim dirençli 52 P. aeruginosa hasta izolatı çalışmaya dahil edildi. Suşların tanımlaması ve antimikrobiyal duyarlılıkları VITEK $2 \circledR$ otomatize sistemi ile çalışıldı. CZA ve C/T etkinliği gradiyent strip test ile (Liofilchem MIC strip test, italya) tespit edildi. Minimal Inhibitör Konsantrasyon yorumu Avrupa Antimikrobiyal Duyarlıık Testi (EUCAST) kılavuzlarına göre yapıldı.

Bulgular: Bu 52 suştan 49 (\%94.2)'u CZA'ya ve 51 (\%98.1)'i C/T'ye duyarlı olarak saptandı. Hem CZA hem de C/T, 3 anti-psödomonal beta-laktam antibiyotiklerin herhangi birinden daha iyi aktiviteye sahipti. izolatların CZA ve C/T'ye duyarlılık oranları benzer olmasına rağmen, $M I C_{50}$ değerlerine göre $C / T\left(M I C_{50} 1 \mu \mathrm{g} / \mathrm{mL}\right), C Z A^{\prime}$ dan $\left(M^{\prime} C_{50^{\prime}} 2 \mu \mathrm{g} / \mathrm{mL}\right)$ iki kat daha etkiliydi.

Sonuç: $C Z A$ ve $C / T$, seftazidim dirençli ve/veya karbapenem dirençli P. aeruginosa izolatlarına karşı iyi aktivite göstermiştir ve bu organizmaların neden olduğu enfeksiyonlar için terapötik seçenekler olarak tercih edilebilirler. Ancak bu yeni antimikrobiyallerin çoklu ilaca dirençli P. aeruginosa'ya karşı etkinliğini değerlendirmek için daha fazla in vitro ve in vivo çalısmalara ihtiyaç vardır.

Anahtar Kelimeler: Seftazidim dirençli Pseudomonas aeruginosa; Karbapenem dirençli Pseudomonas aeruginosa; Seftazidimavibaktam; Seftolozan-tazobaktam

\section{INTRODUCTION}

Pseudomonas aeruginosa is a non-fermentative gram-negative bacillus that causes a wide range of serious clinical infections, including hospital-acquired pneumonia, ventilator-associated pneumonia (VAP), bacteremia, urinary tract infections and skin infections ${ }^{[1]}$. It is the greatest cause of nosocomial infections and is responsible for $\sim 10 \%$ of all hospital-acquired infections worldwide. Also, iitt rarely affects healthy individuals, but causes high morbidity and mortality in immunocompromised individuals and especially in cystic fibrosis (CF) patients $^{[2]}$.

$P$. aeruginosa is difficult to treat with currently available antibiotics[3]. Additionally, the World Health Organization (WHO) has recently listed carbapenem-resistant $P$. aeruginosa as one of three bacterial species in which there is a critical need for the development of new antibiotics to treat infections ${ }^{[4]}$. $P$. aeruginosa displays resistance to a variety of antibiotics, including $\beta$-lactams, quinolones, and aminoglycosides. Generally, the major mechanisms can be classified into intrinsic, acquired, and adaptive resistance ${ }^{[5]}$.
Development of new antibiotics or alternative therapeutic strategies are urgently required because conventional antibiotic therapies against $P$. aeruginosa infections have become increasingly ineffective due to the rise of multidrug-resistant strains ${ }^{[6]}$. Ceftolozane-tazobactam (C/T) and ceftazidime-avibactam (CZA) are two newer betalactam-beta-lactamase inhibitor combinations with broad-spectrum activity against Gram-negative bacteria, including MDR $P$. aeruginosa ${ }^{[7]}$. In late 2014/early 2015, U.S. Food and Drug Administration (FDA) approved both antimicrobial agents for the treatment of complicated urinary tract infections and complicated intra-abdominal infections caused by $P$. aeruginosa ${ }^{[8]}$.

Limited data exists regarding the comparative activity of $\mathrm{CZA}$ and $\mathrm{C} / \mathrm{T}$ against ceftazidime-resistant $P$. aeruginosa isolates in Turkey. In this study, it was aimed to evaluate the in vitro activity of $\mathrm{CZA}$ and $\mathrm{C} / \mathrm{T}$ against ceftazidime resistance $P$. aeruginosa clinical isolates recovered from in a tertiary hospital in Turkey and to compare the activity of CZA, C/T and anti-pseudomonal beta-lactam antibiotics (piperacillin-tazobactam, 
cefepime, imipenem, meropenem) against these isolates.

\section{MATERIALS and METHODS}

\section{Bacterial Isolates}

A total of 52 non-duplicate ceftazidime resistance $P$. aeruginosa clinical isolates from Samsun Training and Research Hospital were included in the study. All isolates were recovered between 2018 and 2019. All clinical samples sent to laboratory were cultured on sheep blood agar and eosin methylene blue agar. After 24-48 hours of incubation, species-level identification and antibiotic sensitivity analyses of the isolates were performed using a VITEK 2 automated system (Biomerieux, France). The clinical sources of the isolates and patient data were obtained retrospectively from the hospital automated records system. All isolates were stored at $-80^{\circ} \mathrm{C}$ in skim milk and sub-cultured twice onto 5\% sheep's blood agar prior to testing. $P$. aeruginosa ATCC 27853 was used as quality control.

\section{Antimicrobial Susceptibility Testing}

MICs of CZA and $\mathrm{C} / \mathrm{T}$ were determined by MIC test strips (Liofilchem, Italy). Firstly, a 0.5 McFarland turbidity standard suspension of each isolate was spread onto Mueller-Hinton agar (BD, USA). The surface of the plate was allowed to dry for $15 \mathrm{~min}$ before applying the MIC test strip. After the application of the MIC test strip, plates were incubated at $35^{\circ} \mathrm{C}$ in ambient air. The MIC results were interpreted according to Clinical and Laboratory Standards Institute (CLSI) criteria in M100-S28 as well as European Committee on Antimicrobial Susceptibility Testing (EUCAST) breakpoint tables (version 9.0) ${ }^{[9,10]}$. Both CLSI and EUCAST have defined CZA MIC breakpoints for $P$. aeruginosa as follows: $\leq 8 \mathrm{mg} /$ $\mathrm{mL}$ (susceptible) and $\geq 16 \mathrm{mg} / \mathrm{mL}$ (resistant). The CLSI has defined $\mathrm{C} / \mathrm{T}$ MIC breakpoints for $P$. aeruginosa as $\leq 4 \mathrm{mg} / \mathrm{mL}$ (susceptible), $8 \mathrm{mg} / \mathrm{mL}$ (intermediate) and $\geq 16 \mathrm{mg} / \mathrm{mL}$ (resistant), while EUCAST has defined $\mathrm{C} / \mathrm{T}$ MIC breakpoints as $\leq 4 \mathrm{mg} / \mathrm{mL}$ (susceptible) and $\geq 8 \mathrm{mg} / \mathrm{mL}$ (resistant).

Multidrug-resistance (MDR) was defined as resistance to at least three of the following: antipseudomonal cephalosporin, piperacillin-tazobactam, meropenem, ciprofloxacin and aminogly- coside ${ }^{[11]}$. Strains sensitive to only colistin and/or aminoglycoside were considered to be extensively drug resistant $(\mathrm{XDR})^{[12]}$.

The study was approved by the Ethics Commission of Samsun Training and Research Hospital SBÜSEAH-KAEK-2020/2/5.

\section{Statistical Analysis}

Data were analyzed using SPSS software (version 17, SPSS Inc. Chicago, IL). Pearson ChiSquare test was used to compare categorical variables.

\section{RESULTS}

A total of 52 clinical isolates of $P$. aeruginosa, only one specimen per site per patient, was considered in this study. $P$. aeruginosa strains were isolated from patients in the intensive care unit $(n=23)$, internal sciences clinics and surgical sciences clinics of our hospital. The clinical sources of the isolates included 14 tracheal aspirate (27\%), 12 urine (23\%), 12 wound (23\%), 11 sputum (21\%), 1 blood, 1 drain and 1 sterile body fluid (2\%) samples. The origin of clinical samples tested in this study is detailed in Table 1.

All isolates $(n=52)$ were resistant to ceftazidime (MIC range $=8-64 \mathrm{mg} / \mathrm{mL}$ ) according to CLSI breakpoints. Among these isolates, 88.5\% (46 of 52) were resistant to ceftazidime and cefepime; $86.5 \%$ (45 of 52) were resistant to ceftazidime and piperacillin-tazobactam, 75\% (39 of 52) were resistant to three traditional anti-pseudomonal $\beta$-lactam agents according to both CLSI and EUCAST criteria. 10 (19.3\%) isolates were sensitive to only colistin and/or aminoglycoside were considered to be XDR and 42 (80.7\%) isolates were considered to be MDR.

Among these 52 strains, 49 (94.2\%) were susceptible to CZA and 51 (98.1\%) to $\mathrm{C} / \mathrm{T}$ (Table 2). Among the 52 ceftazidime-resistant $P$. aeruginosa isolates; 26 strains (50\%) were resistant to MEM and/or imipenem. Among these 26 strains, the susceptibility rates to $\mathrm{CZA}$ and $\mathrm{C} / \mathrm{T}$ were $92.3 \%(24 / 26)$ and $100 \%(26 / 26)$ respectively. Other antibiotic susceptibilities are shown in Table 2.

Figure 1 shows $\mathrm{CZA}$ and $\mathrm{C} / \mathrm{T}$ MIC distributions for 52 ceftazidime resistant $P$. aeruginosa 
Table 1. The origin of clinical samples (services and samples)

\begin{tabular}{lcccccc}
\hline Sample & $\begin{array}{c}\text { Intensive } \\
\text { care }\end{array}$ & $\begin{array}{c}\text { Internal } \\
\text { medicine }\end{array}$ & $\begin{array}{c}\text { Surgery } \\
\text { clinics }\end{array}$ & $\begin{array}{c}\text { Chest } \\
\text { diseases }\end{array}$ & $\begin{array}{c}\text { Dermatology } \\
\text { Total }\end{array}$ \\
\hline Urine & 3 & 6 & 3 & 0 & 0 & 12 \\
Blood & 1 & 0 & 0 & 0 & 0 & 1 \\
Wound & 5 & 3 & 3 & 0 & 1 & 12 \\
Sputum & 4 & 2 & 0 & 5 & 0 & 11 \\
Endotracheal aspirat & 13 & 0 & 0 & 1 & 0 & 14 \\
Drain & 0 & 0 & 1 & 0 & 0 & 1 \\
Pleura & 0 & 0 & 1 & 0 & 0 & 1 \\
Total & 26 & 11 & 8 & 6 & & 52
\end{tabular}

Table 2. In vitro activities of CZA and C/T and susceptibility profile to other antibacterial afor the $\mathbf{5 2}$ ceftazidime-resistant and/or carbapenem-resistant $P$. aeruginos $a$ isolates

\begin{tabular}{|c|c|c|c|c|}
\hline Organism group/antimicrobial agent & $\begin{array}{c}\text { MIC range } \\
(\mathrm{mg} / \mathrm{L})\end{array}$ & $\mathrm{MIC}_{50}$ & $\mathrm{MIC}_{90}$ & Susceptibility no, (\%) \\
\hline \multicolumn{5}{|l|}{ P. aeruginosa CAZ-R } \\
\hline CZA & $0.50-32$ & 2 & 4 & $49 / 52(94.2)$ \\
\hline $\mathrm{C} / \mathrm{T}$ & $0.12-8$ & 1 & 2 & $51 / 52(98.1)$ \\
\hline Cefepime & & & & $6 / 52(11.5)$ \\
\hline Piperacillin tazobactam & & & & $7 / 52(13.5)$ \\
\hline Imipenem & & & & $27 / 52(51.9)$ \\
\hline Meropenem & & & & $28 / 52(53.8)$ \\
\hline Ciprofloxacin & & & & $29 / 52(55.8)$ \\
\hline Levofloxacin & & & & $32 / 52(61.5)$ \\
\hline Amicasin & & & & $47 / 52(90.4)$ \\
\hline Gentamycin & & & & $39 / 52(75)$ \\
\hline Colistin & & & & $52 / 52(100$ \\
\hline \multicolumn{5}{|l|}{ P. aeruginosa CAZ-R + IMI and/or MER-R } \\
\hline CZA & $1-32$ & 2 & 4 & $24 / 26(92.3)$ \\
\hline $\mathrm{C} / \mathrm{T}$ & $0.19-4$ & 0.75 & 1.5 & $26 / 26(100)$ \\
\hline Cefepime & & & & $2 / 26(7.6)$ \\
\hline Piperacillin tazobactam & & & & $2 / 26(7.6)$ \\
\hline Ciprofloxacin & & & & $11 / 26(42.3)$ \\
\hline Levofloxacin & & & & $12 / 26(46.1)$ \\
\hline Amicasin & & & & $24 / 26(92.3)$ \\
\hline \multicolumn{5}{|l|}{ Gentamycin } \\
\hline Colistin & & & & $\begin{array}{c}19 / 26(73) \\
26 / 26(100)\end{array}$ \\
\hline
\end{tabular}


isolates. Among 52 isolates, two isolates were resistant to $\mathrm{CZA}$ but susceptible to $\mathrm{C} / \mathrm{T}$ and one isolate was resistant to both $\mathrm{CZA}$ and $\mathrm{C} / \mathrm{T}$ according to EUCAST breakpoints but intermediate to $\mathrm{C} / \mathrm{T}$ according to CLSI breakpoints. The MIC50 values of $\mathrm{CZA}$ and $\mathrm{C} / \mathrm{T}$ were $2 \mathrm{mg} / \mathrm{mL}$ and 1 $\mathrm{mg} / \mathrm{mL}$, respectively. Using $\mathrm{MIC}_{50}$ values, $\mathrm{C} / \mathrm{T}$ was two-fold more potent than CZA.

\section{DISCUSSION}

In recent years, it has been observed that in some geographical regions the prevalence of MDR and XDR $P$. aeruginosa strains has increased between $15 \%$ and $30 \%[13,14]$. One of the main consequences of multidrug resistance is the difficulty of selecting appropriate empirical antibiotic treatment. Patients with infections due to MDR/XDR pathogens are at an increased risk of receiving inadequate initial antimicrobial therapy ${ }^{[15]}$.

Especially the increase in carbapenem resistance among $P$. aeruginosa clinical isolates is worrisome because there has been little progress in the development of new antimicrobial agents targeting this organism ${ }^{[16,17]}$. Although in vitro data show that colistin seems to be the most effective agent against resistant $P$. aeruginosa strains, its pharmacokinetic properties and nephrotoxicity limit its use in the treatment of these types of infections ${ }^{[18]}$.

Several in vitro studies have demonstrated that ceftazidime-avibactam and ceftolozane-tazobactam display good activity against MDR/XDR $P$. aeruginosa strains collected in different parts of the world with inhibition rates varying between $66.1 \%$ and $86.5 \%$ for CZA; $55 \%$ and $96.6 \%$ for $\mathrm{C} / \mathrm{T}$ (19-22). There are only two studies from Turkey assessing the in vitro activitity of CZA and $\mathrm{C} / \mathrm{T}$ against clinical isolates of $P$. aeruginosa. In their study Mirza et al. have demonstrated susceptibility rates for CZA and C/T were $83.3 \%$ and $82.4 \%$, respectively against 102 meropenemnon-susceptible $P$. aeruginosa isolates ${ }^{[23]}$. The other study was conducted by Aydemir et al., and in their study, susceptibility rates against $\mathrm{CZA}$ and $\mathrm{C} / \mathrm{T}$ in MDR and XDR $P$. aeruginosa strains have been found as 78.2\% and 68.8\%, respectively ${ }^{[24]}$. In our study, susceptible rates for CZA and C/T were $94.2 \%$ and $98.1 \%$, against
CAZ resistant $P$. aeruginosa strains; $92.3 \%$ and 100\% against 26 CAZ-R + IMI and/or MER-R $P$. aeruginosa isolates, respectively. These results showed that our CZA and $\mathrm{C} / \mathrm{T}$ susceptibility rates were higher than these two studies. Probably, patterns of antibiotic usage resistance mechanisms and susceptibility rates to different antibiotics may differ by geographical region in the world, as well as Turkey, and could have affected the results.

Ceftolozane is a new oxyimino-aminothiazolyl cephalosporin with a structure similar to ceftazidime, but it is less susceptible to hydrolysis by $\mathrm{AmpC}$ and less affected by porin loss than ceftazidime ${ }^{[8]}$. In our study, two isolates were resistant to $\mathrm{CZA}$ but susceptible to $\mathrm{C} / \mathrm{T}$ and one isolate was resistant to both $\mathrm{CZA}$ and $\mathrm{C} / \mathrm{T}$. All isolates that were resistant to either ceftazidimeavibactam or ceftolozane-tazobactam were also resistant to all three beta-lactam agents. Although the number of isolates is low; according to these results, we can say that in our study $\mathrm{C} / \mathrm{T}$ is more effective than CZA in ceftazidime resistant $P$. aeruginosa isolates. This finding is consistent with the findings by Buehrle et al. ${ }^{[25]}$.

This study has a few limitations. Firstly, the low number of tested isolates and the inclusion of a single hospital limit the statistical power of these results. Secondly, the mechanisms of resistance to $\mathrm{CZA}$ and $\mathrm{C} / \mathrm{T}$ were not explored in this study. Unfortunately, there were no studies about the resistance mechanisms for CZA and $\mathrm{C} / \mathrm{T}$ among $P$. aeruginosa isolates in Turkey.

In summary, in vitro studies have shown that $\mathrm{CZA}$ and $\mathrm{C} / \mathrm{T}$ might be a good selection for the treatment of MDR/XDR $P$. aeruginosa infections, but clinical experience is currently limited. We hope that new studies about determination of resistance mechanisms may be helpful for development of effective strategies to cope with resistance and epidemiological purposes.

\section{ETHICS COMMITTEE APPROVAL}

The ethical approval for this study was obtained from Samsun Training and Research Hospital (Protocol No: SBÜSEAH-KAEH-2020/2/5).

\section{CONFLICT of INTEREST}

None of the authors had conflict of interest. 


\section{AUTHORSHIP CONTRIBUTIONS}

Concept and Design: MB, EB, HI

Data Collection or Processing: MB, EB

Analysis/Interpretation: MB, Hi

Literature Search: MB, EB, Hi

Writing: MB

Final Approval: MB, EB, Hi

\section{REFERENCES}

1. Cai Y, Yang D, Wang J, Wang R. Amikacin and cefoperazone/sulbactam alone or in combination against carbapenem-resistant Pseudomonas aeruginosa. Diagnostic Microbiol Infect Dis 2018;91(2):186-90.

2. Sadikot R T, Blackwell T S, Christman I W, \& Prince A S. Pathogen-host interactions in Pseudomonas aeruginosa pneumonia. Am J Respir Crit Care Med 2005;171(11):1209-23.

3. El Solh AA, Alhajhusain A. Update on the treatment of Pseudomonas aeruginosa pneumonia. I Antimicrob Chemother 2009;64(2):229-38.

4. Tacconelli E, Magrini N, Carmeli Y, Harbarth S, Kahlmeter G, Kluytmans J, et al. Global priority list of antibiotic-resistant bacteria to guide research, discovery, and development of new antibiotics. World Health Organization 2017. Available from: http://www.who.int/medicines/publications/ WHO-PPLShort_Summary_25Feb ET_NM_WHO.pdf (Accessed date: 19 September 2020).

5. Pang Z, Raudonis R, Glick BR, Lin TJ, Cheng Z. Antibiotic resistance in Pseudomonas aeruginosa: mechanisms and alternative therapeutic strategies. Biotech $\mathrm{Adv}$ 2019;37(1):177-92.

6. Chatterjee M, Anju CP, Biswas L, Anil Kumar V, Gopi Mohan C, Biswas R. Antibiotic resistance in Pseudomonas aeruginosa and alternative therapeutic options. Int J Med Microbiol 2016;306(1):48-58.

7. Livermore DM, Mushtaq S, Ge Y, Warner M. Activity of cephalosporin CXA-101 (FR264205) against Pseudomonas aeruginosa and Burkholderia cepacia group strains and isolates. Int J Antimicrobial Agents 2009;34(5):402-6.

8. Juan C, Zamorano L, Pérez IL, Ge Y, Oliver A; Spanish Group for the Study of Pseudomonas; Spanish Network for Research in Infectious Diseases. Activity of a new antipseudomonal cephalosporin, CXA-101 (FR264205), against carbapenem-resistant and multidrug-resistant Pseudomonas aeruginosa clinical strains. Antimicrob Agents Chemother 2010;54(2):846-51.

9. Clinical and Laboratory Standards Institute (CLSI) Performance standards for antimicrobial susceptibility testing: twenty eighth informational supplement M100-S28. Wayne, PA: Clinical and Laboratory Standards Institute; 2018 (Accessed date: 2 September 2020).
10. European Committee and Antimicrobial Susceptibility Testing (EUCAST). Breakpoint tables for interpretation of MICs and zone diameters, version 9.0. http://www.eucast.org/ clinical_breakpoints/ (Accessed date: 10 November 2020).

11. Karlowsky JA, Kazmierczak KM, Bouchillon SK, de Jonge BLM, Stone GG, Sahm DF. In vitro activity of ceftazidime-avibactam against clinical isolates of enterobacteriaceae and Pseudomonas aeruginosa collected in asia-pacific countries: Results from the INFORM Global Surveillance Program, 2012 to 2015. Antimicrob Agents Chemother 2018;62(7):e02569-17.

12. Díaz-Cañestro $M$, Periañez $L$, Mulet $X$, Martin-Pena $M L$, Fraile-Ribot PA, Ayestarán I, et al. Ceftolozane/tazobactam for the treatment of multidrug-resistant Pseudomonas aeruginosa: experience from the Balearic Islands. Eur I Clin Microbiol Infect Dis 2018;37:2191-200.

13. Peña C, Cabot G, Gómez-Zorrilla S, Zamorano L, Ocampo-Sosa A, Murillas J, et al. Influence of virulence genotype and resistance profile in the mortality of Pseudomonas aeruginosa bloodstream infections. Clinical infectious diseases: an official publication of the Infect Dis Soc Am 2015;60(4):539-48.

14. Sader HS, Castanheira M, Duncan LR, Flamm RK. Antimicrobial susceptibility of enterobacteriaceae and Pseudomonas aeruginosa isolates from United States Medical Centers Stratified by infection type: Results from the International Network for Optimal Resistance Monitoring (INFORM) Surveillance Program, 2015-2016. Diagn Microb Infect Dis 2018;92(1):69-74.

15. Horcajada JP, Montero M, Oliver A, Sorlí L, Luque S, Gómez-Zorrilla S, Benito N, Grau S. Epidemiology and treatment of multidrug-resistant and extensively drug-resistant Pseudomonas aeruginosa Infections. Clin Microbiol Rev 2019;32(4):e00031-19.

16. Wi YM, Choi JY, Lee JY, Kang Cl, Chung DR, Peck KR, et al. Emergence of colistin resistance in Pseudomonas aeruginosa ST235 clone in South Korea. Int J Antimicrob Agents 2017;49(6):767-9.

17. Wi YM, Choi JY, Lee JY, Kang Cl, Chung DR, Peck KR et al. Antimicrobial effects of $\beta$-Lactams on imipenem-resistant ceftazidime-susceptible Pseudomonas aeruginosa. J Antimicrob Chemother 2017;61(6):e00054-17.

18. Dalfino L, Puntillo F, Ondok MJ, Mosca A, Monno R, Coppolecchia $S$, et al. Colistin-associated acute kidney injury in severely ill patients: a step toward a better renal care? A prospective cohort study. Clin Infect Dis 2015;61(12):1771-7.

19. Stone GG, Newell P, Gasink LB, Broadhurst $H$, Wardman $A$, Yates $K$, et al. Clinical activity of ceftazidime/avibactam against MDR Enterobacteriaceae and Pseudomonas aeruginosa: pooled data from the ceftazidime/avibactam Phase III clinical trial programme. I Antimicrob Chemother 2018;73(9):2519-23. 
20. Sader HS, Castanheira M, Flamm RK, Mendes RE, Farrell DJ, Jones RN. Ceftazidime/avibactam tested against Gram-negative bacteria from intensive care unit (ICU) and non-ICU patients, including those with ventilator-associated pneumonia. Int J Antimicrob Agents 2015;46(1):53-9.

21. Carmeli Y, Armstrong J, Laud PJ, Newell P, Stone G, Wardman $A$, et al. Ceftazidime-avibactam or best available therapy in patients with ceftazidime-resistant Enterobacteriaceae and Pseudomonas aeruginosa complicated urinary tract infections or complicated intra-abdominal infections (REPRISE): a randomised, pathogen-directed, phase 3 study. Lancet Infect Dis 2016;16(6):661-73.

22. Shortridge D, Pfaller MA, Castanheira M, Flamm RK. Antimicrobial activity of ceftolozane-tazobactam tested against Enterobacteriaceae and Pseudomonas aeruginosa collected from patients with bloodstream infections isolated in United States hospitals (2013-2015) as part of the Program to Assess Ceftolozane-Tazobactam Susceptibility (PACTS) surveillance program. Diagn Microbiol Infect Dis 2018;92(2):158-63.

23. Mirza $H C$, Hortaç E, Koçak $A A$, Demirkaya $M H$, Yayla

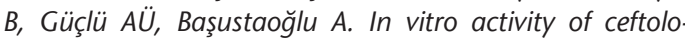
zane-tazobactam and ceftazidime-avibactam against clinical isolates of meropenem-non-susceptible Pseudomonas aeruginosa: A two-centre study. I Glob Antimicrob Resist 2020;20:334-8
24. Aydemir Ö, Terzi HA, Köroğlu M, Altındiş M. In vitro activity of ceftolozane/tazobactam and ceftazidime/avibactam against carbapenemase-producing Pseudomonas aeruginosa. Mediterranean J Infect Microbes Antimicrob 2019;8:5.

25. Buehrle DJ, Shields RK, Chen L, Hao B, Press EG, Alkrouk $A$, et al. Evaluation of the in vitro activity of ceftazidime-avibactam and ceftolozane-tazobactam against meropenem-resistant Pseudomonas aeruginosa isolates. Antimicrob Agents Chemother 2016;60(5):3227-31.

\section{Address for Correspondence/Yazıșma Adresi}

Dr. Melek BILGiN

Clinic of Medical Microbiology,

Health Sciences University

Samsun Training and Research Hospital,

Samsun-Turkey

E-posta: drmelekbilgin@gmail.com 